\title{
LATE CRETACEOUS-EARLY TERTIARY ULTRABASIC MAGMATISM IN THE WESTERN PART OF THE STATE OF RIO DE JANEIRO, BRAZIL
}

\author{
C.Riccomini ${ }^{1}$ \\ M.S.Melo ${ }^{2}$ \\ J.M.V.Coutinho'
}

\section{INTRODUCTION}

Several occurrences of dikes of ultrabasic rocks and lava flows of similar composition have been discovered during the last seven years in the vicinity of Resende and Volta Redonda basins, western part of the State of Rio de Janeiro, Brazil. Although the available geological data concerning these rocks are still scarce, they indicate the existence of a probable dike swarm in the region, whose preliminary characterization is the subject of this paper.

\section{GEOLOGICAL FRAMEWORK}

The western part of the State of Rio de Janeiro comprises granitic, gneissic and migmatitic terranes of Proterozoic age as well as ENE to E-W shear zones with associated cataclastic rocks related to the Brasiliano/Pan African Cycle. Dikes and sills of basic rocks of Upper Jurassic to Lower Cretaceous age (AMARAL et al., 1966) mark the beginning of the Mesozoic tectono-magmatic reactivation of the Brazilian Platform in the region. Alkaline rocks present in the area include the large

\footnotetext{
'Instituto de Geociências, Universidade de São Paulo, Caixa Postal, 20899, 01498, São Paulo, SP, Brazil.

${ }^{2}$ Instituto de Pesquisas Tecnológicas do Estado de São Paulo, São Paulo, SP, Brazil.
} 
Itatiaia, Passa Quatro and Morro Redondo Massifs and coeval dikes and sills of the Late CretaceousEarly Tertiary (AMARAL et al., 1967). During the Paleogene, mainly in the Oligocene, the normal reactivation of the Brasiliano/Pan-African shear zones led to the formation of the Resende and Volta Redonda basins (RICCOMINI, 1989).

RICCOMINI et al. (1983) have described Eocene-Oligocene extrusive rocks, petrographically characterized as ankaramites, interlayered with fanglomeratic deposits of the Resende Formation in the Casa de Pedra Graben (Volta Redonda Basin), about $4.5 \mathrm{~km}$ southeast of the city of Volta Redonda. The lava flows, little more than $\mathbf{2 0} \mathrm{m}$ in thickness, crop out in a semi-circular depression about $1 \mathrm{~km}$ in diameter. The presence of sandy-clayey sediments between lava flows as well as textural variations are indicative of the presence of at least two superimposed flows. Rocks of similar nature and possibly synchronous with those of Casa de Pedra have also been described overlying Palaeocene limestones in the Itaboral Basin, close to Niterói, Rio de Janeiro (KLEIN \& VALENÇA, 1984).

A dozen occurrences of ultrabasic dikes are known in the vicinity of the Resende Basin. Similar rocks were discovered recently in the Caçapava-Pindamonhangaba region, Taubaté Basin, State of São Paulo. These dikes are centimetric to metric in thickness, preferentially cutting Precambrian basement rocks but locally cutting Mesozoic basic rocks and Late Cretaceous-Early Tertiary alkaline rocks as well. Direct contacts between these dikes and Paleogene sediments has not yet been observed. Almost all these dikes are petrographically classified as pyroxene-biotite lamprophyres with subordinate occurrences of pyroxene-olivine lamprophyres.

\section{PETROGRAPHY}

\section{Ankaramites}

These rocks, which constitute the lava flows of the Casa de Pedra Graben, are darkgrey with massive to amygdaloidal structure. Microscopically, they show a porphyritic/panidiomorphic texture. The rock is composed of $10-15 \%$ pyroxene (titaniferous augite) and $5-10 \%$ olivine (in part serpentinized) phenocrysts. The groundmass contains about $30-40 \%$ pyroxene (titaniferous augite) and $10 \%$ opaque, microcrystalline minerals, within a poikilitic plagioclase and analcime-rich leucocratic mass. Scarce submillimetric to millimetric cavities are filled by carbonates and/or chalcedony. Nepheline occurs as autolithic concentrations and as poikilitic crystals, optically similar to plagioclase, dispersed in the groundmass. The plagioclase+nepheline+chalcedony+analcime mixture 
corresponds to $30-40 \%$ of the rock.

\section{Pyroxene-biotite lamprophyres}

Macroscopically, these rocks exhibit a dark-grey color and a massive to locally amygdaloidal structure with centimetric phenocrysts of biotite and centimetric irregular masses of greyish-green fluorite. Microscopically, the rock shows porphyritic/panidiomorphic texture with $20-30 \%$ biotite and $10-20 \%$ pyroxene (titaniferous augite) phenocrysts distributed in a groundmass of $20 \%$ microcrystalline pyroxene (titaniferous augite), partially serpentinized, $10 \%$ opaque minerals, and about $30 \%$ as a leucocratic mixture rich in plagioclase and analcime. Carbonate and analcime also occurs as millimetric amygdaloidal fillings.

\section{Pyroxene-olivine lamprophyres}

Macroscopically, the rocks exhibit a grey color and a massive, locally amygdaloidal structure. Microscopically, these lamprophyres show a porphyritic/ panidiomorphic texture. Euhedral phenocrysts of augite (10\% of the rock) and olvine (5-10\%), occasionally serpentinized, occur in a groundmass with microcrystalline augite $(10-20 \%)$ and opaque minerals $(5 \%)$ within a leucocratic mass (55-60\% of the rock) rich in plagioclase, nepheline and analcime. Xenocrysts of feldspar and quartzfeldspar xenoliths present reaction margins with the groundmass.

\section{GEOCHEMICAL DATA}

Table 1 shows the locations of the studied rock samples and Table 2 presents the results of chemical analyses performed by the Chemistry and Chemical Engineering Division of the Institute of Technological Research of the State of São Paulo S.A. For comparison, this table also includes chemical data on ankaramitic rocks from the Itaboral Basin, Rio de Janeiro (KLEIN \& VALENÇA, 1984), and on the ankaramite dike from the type-locality in Ankaramy, Madagascar (LACROIX, 1916 apud JOHANNSEN, 1937).

The chemical data show strong similarities between the extrusive rocks of the Casa de Pedra Graben (sample VR-01) and the pyroxene-olivine lamprophyre dike cutting Precambrian basement rocks of the Volta Redonda Basin (VR-02). This also seems to be true for the pyroxene-biotite 
Table 1 - Nature and location of studied samples.

Sample
VR-01
VR-02
RE-06
RE-07

Nature

Latitude

Longitude

ankaramite

$22^{\circ} 32^{\prime} 18^{\prime \prime S}$

$44^{\circ} 04^{\prime} 25^{\prime \prime} \mathrm{W}$

pyroxene-olvine lamprophyre

$22^{\circ} 35^{\prime} 50^{\prime \prime S}$

$44^{\circ} 05^{\prime} 177^{\prime \prime W}$

piroxene-blotite lamprophyre

$22^{\circ} 22^{\prime} 24^{\prime \prime} \mathrm{S}$

$44^{\circ} 13^{\prime} 05^{\prime \prime} \mathrm{W}$

pyroxene-blotite lamprophyre

$22^{\circ} 32^{\prime} 18^{\prime \prime} \mathrm{S}$

$44^{\circ} 35^{\prime} 06^{\prime} \mathrm{W}$

Table 2 - Geochemical data (wt\%).

$\mathrm{AN}_{2} \mathrm{O}_{3}$

$\mathrm{Fe}_{2} \mathrm{O}_{3}$

$\mathrm{FeO}$

$\mathrm{TlO}_{2}$

$\mathrm{CaO}$

$\mathrm{MgO}$

$\mathrm{Na}_{2} \mathrm{O}$

$\mathrm{K}_{2} \mathrm{O}$

$\mathrm{MnO}$

$\mathrm{P}_{2} \mathrm{O}_{5}$

$\mathrm{CO}_{2}$

I.o.1.

Total

99.9

$\begin{array}{lll}42.2 & 44.9 & 39.6\end{array}$

$13.2 \quad 12.6$

11.8

37.9

40.9

12.6

40.7

43.27

$4.2 \quad 4.3$

5.4

11.4

4.5

12.6

7.54

$\begin{array}{ll}6.8 & 5.8\end{array}$

6.5

5.45

4.8

2.32

$2.5 \quad 3.0$

9.7

5.17

6.18

12.1

11.3

4.2

3.7

3.7

1.25

10.1

11.8

14.5

14.4

13.72

3.2

9.4

6.6

10.2

6.3

6.2

17.65

$3.7 \quad 2.2$

1.7

2.4

2.3

1.26

1.2

4.1

3.7

0.76

0.68

1.14

$0.2 \quad 0.2$

1.0

0.21

0.21

1.3

0.38

$\begin{array}{ll}0.9 & 0.9\end{array}$

1.2

2.3

1.3

n.d.

4.32

$3.3 \quad 2.3$

6.3

4.7

n.d.

7.04

4.54

6.99$$
4.54
$$

99.8

99.9

99.9

99.61

99.10

99.25 
lamprophyres from the vicinity of the Resende Basin (RE-06 and RE-07) in spite of high values for loss on ignition.

In the diagram of DE LA ROCHE et al. (1980), the rock samples from the Volta Redonda (VR-01 and VR-02) and Itaboral basins, as well as one sample from Resende (RE-07), are grouped in the basanite field. The second sample from Resende (RE-06) is located in the tephrite field, and the data from Ankaramy in the picrite field (Fig. 1).

On the other hand, in the TAS (Total Alkalies-Silica) diagram of the IUGS Commission on Systematics in Petrology (SABINE 1989), the data from Volta Redonda and Ankaramy plot within the basanite and picrite (picro-basalt) fields, respectively, whereas those from Itaborai and Resende are located in the foidite field (Fig. 2).

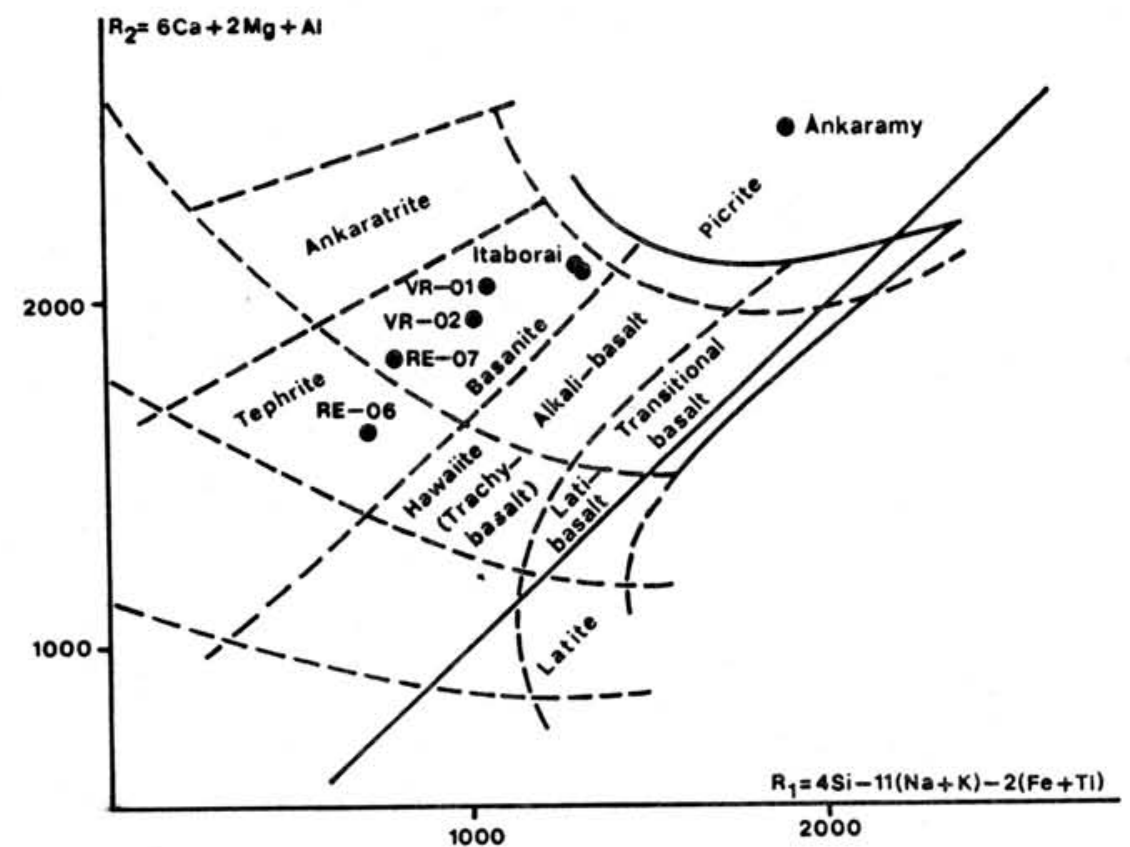

Figure $1-R_{1}-R_{2}$ diagram of DE LA ROCHE et al., (1980) for volcanic rocks. Samples as referred in Table 1. 


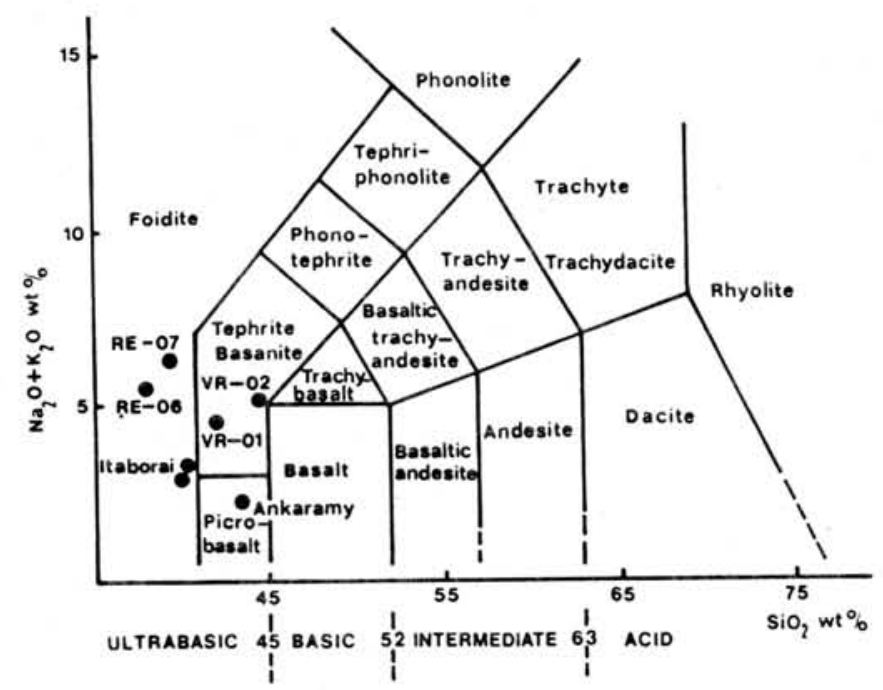

Figure 2 - The total alkalis-silica (TAS) diagram of IUGS Commission on Systematics in Petrology (SABINE, 1989) for use with volcanic rocks when modal data are not available. Samples as referred in Table 1.

\section{K/Ar AGE DETERMINATIONS}

Duplicate K/Ar whole rock determinations were performed on a sample from the Casa de Pedra lava flows, furnishing values of $43.8 \pm 6.2 \mathrm{Ma}$ and $41.7 \pm 5.7 \mathrm{Ma}$ (RICCOMINI et al., 1983).

A single K/Ar determination each on biotites from pyroxene-biotite dike RE-06, and on a whole rock sample from pyroxene-olivine dike VR-02 yielded ages of $84.0 \pm 3.0 \mathrm{Ma}$ and $69.6 \pm 2.9$ Ma, respectively (Table 3), both ages significantly older than the Casa de Pedra lava flows.

The 69.6 $\pm 2.9 \mathrm{Ma}$ age (VR-02) may still correlate with the age of the Itatiaia (average age of $73 \mathrm{Ma}$; LAUAR, 1988) and Morro Redondo(67.2 $\pm 4.0 \mathrm{Ma}$; KINOSHITA, unpublished data, apud LAUAR, 1988) alkaline massifs. The $84.0 \pm 3.0 \mathrm{Ma}$ age for dike RE-06, on the other hand, is problematical as this value is older than that for the alkaline massifs that are cut locally by ultrabasic dikes.

There is the possibility of excess argon or contamination of the dikes samples, especially as dike RE-06 cuts a Mesozoic diabase dike and contains centimetric xenoliths of Precambrian gneissic country rocks at its contact.

Another aspect to be considered is the fact that the potassium contents measured by spectrometry for the K/Ar age determinations (Table 3 ) are significantly higher than those measured by atomic absorption (Table 2), which suggests analytical problems for the absorption analysis because of their lower precision. 
Thus, in spite of chemical similarities, the geochronological data do not permit correlation between the lava flows (VR-01) and the pyroxene-olivine lamprophyre dike (VR-02).

Table 3 - K/Ar analytical data.

\begin{tabular}{|c|c|c|c|c|c|c|}
\hline $\begin{array}{l}\text { Laboratory } \\
\text { number }\end{array}$ & $\begin{array}{c}\text { Fleld } \\
\text { number }\end{array}$ & \%K & $\operatorname{Ar}^{40}(*)$ & $\% A r^{40}$ & Age(Ma) & Material \\
\hline 4956 & VR-01 & 0.8470 & 1.4479 & 64.41 & $43.8 \pm 6.2$ & whole rock \\
\hline $4992=4956$ & VR-01 & 0.8470 & 1.3799 & 62.03 & $41.7 \pm 5.7$ & whole rock \\
\hline 6354 & VR-02 & 1.8503 & 5.10 & 16.1 & $69.6 \pm 2.9$ & whole rock \\
\hline 6351 & RE-06 & 6.4870 & 21.67 & 25.6 & $84.0 \pm 3.0$ & biotite \\
\hline
\end{tabular}

\section{CONCLUDING REMARKS}

The Casa de Pedra lava flows seem to be probably related to the extreme crustal thinning imposed by transtension caused by left-lateral, E-W transcurrence during a pull-apart stage in the development of the Volta Redonda Basin (RICCOMINI 1989). The principal WNW and secondary ENE directions of ultrabasic dikes are not incompatible with such a stress field.

The ultrabasic magmatism of the western part of the State of Rio de Janeiro still needs additional geochronological and petrographical data in order to be understood more fully. The obtainment of such data, however, depends on the discovery of new occurrences of unweathered ultrabasic rocks.

\section{AKNOWLEDGEMENTS}

Thanks are due to the staff of the Geochronological Research Center (Institute of Geosciences, University of São Paulo) for K/Ar age determinations.

\section{REFERENCES}


AMARAL, G.; CORDANI, U.G.; KAWASHITA, K.; REYNOLDS, J.H. (1966) Potassium-argon dates of basaltic rocks from Southern Brazil. Geochimica et Cosmochimica Acta, 30:159-189.

AMARAL, G.; BUSHEE, J.; CORDANI, U.G.; KAWASHITA, K.; REYNOLDS, J.H. (1967) Potassium-argon ages of alkaline rocks form Southern Brazil. Geochimica et Cosmochimica Acta, 31:117-142.

DE LA ROCHE, H.; LETERRIER, J.; GRANCLAUDE, P.; MARCHAL, M. (1980) A classification of volcanic and plutonic rocks using R1R2-diagram and major-element analyses - its relationships with current nomenclature. Chemical Geology, 29:183-210.

JOHANNSEN, A. (1937) A descriptive petrography of igneous rocks. Chicago, The University of Chicago Press. V.3.

KLEIN, V.C. \& VALENÇA, J.G. (1984) Estruturas almofadadas em derrame ankaramítico na Bacia de São José de Itaboral, Rio de Janeiro. In: CONGRESSO BRASILEIRO DE GEOLOGIA, 33, Rio de Janeiro, 1989. Anais. Rio de Janeiro, SBG, V.9, p.4335-4345.

LACROIX, A. (1916) Sur quelques roches volcaniques mélanocrates des possessions françaises de l'océan Indien et du Pacifique. Comptes Rendus, 163:182-183.

LAUAR, C.R.M. (1988) Paleomagnetismo e correlações com idades radiométricas: alguns exemplos. São Paulo, 29p. (Unpublished seminar, Instituto de Geociências-USP).

RICCOMINI, C. (1989) O rift continental do sudeste do Brasil. São Paulo, 256p. (Tese de Doutorado Instituto de Geociências/USP).

RICCOMINI, C.; MELO, M.S.; ALMEIDA, F.F.M.; CARNEIRO, C.D.R.; MIOTO, J.A.; HASUI, Y. (1983) Sobre a ocorrência de um derrame de ankaramito na Bacia de Volta Redonda (RJ) e sua importância na datação das bacias tafrogênicas continentais do sudeste brasileiro. In: SIMPÓSIO REGIONAL DE GEOLOGIA, 4, São Paulo, 1983. Resumos. São Paulo, SBG. p.23-24.

SABINE, P.A. (1989) Setting standards in petrology: The Commission on Systematics in Petrology. Episodes, 13:84-86. 